\title{
The new national environmental management: Waste Act; a shift in waste management approach in South Africa
}

\author{
O. Baloyi \& K. Masinga \\ Department of Environmental Affairs (DEA), South Africa
}

\begin{abstract}
South Africa has been in the process of strengthening its regulatory framework through the development of legislation, regulations, norms and standards to facilitate better management of waste. One such legislation is the National Environmental Management: Waste Act, 2008 (Act No. 59 of 2008) which led to the adoption of a new approach in waste management. Traditional ways of dealing with waste have a considerable environmental footprint, not only from landfill methane emissions but also from the energy and raw materials needed to collect and move it around. It is estimated that South Africa generates millions of tons of waste from household, commerce and industry. Although current data on waste flows is incomplete, it was estimated that for the between March 2006 to April 2007, about 24,115,402 tons of general waste was disposed of in landfills during that year (DEAT, 2007). This figure will increase as waste services are extended, and necessitate a significant increase in the recycling rate and greater diversion of waste from landfill through waste to energy recovery, treatment and reuse programs. Currently, much of this waste ends up in waste landfills where it biodegrades and generates methane gas which contributes to the total greenhouse gas emissions leading to climate change. In July of 2009, the new Waste Act which governs waste management in South Africa came into effect. This landmark legislation seeks to address the problems South Africa has over waste by instituting mechanisms of waste avoidance, minimisation, reuse, recycling, recovery, appropriate collection, transport services and environmentally sound treatment and disposal. Interestingly, the new Waste Act also introduces an element of remediation of contaminated land, a new provision in waste management legislation in the country. With the firm legislative foundation and
\end{abstract}


implementation thereof, South Africa will build healthier communities, a cleaner environment and a more prosperous and successful life for everyone.

Keywords: waste, waste hierarchy, regulations, waste strategy, waste licence, waste information, reuse, recycling, disposal.

\section{Overview of waste management legislation in South Africa}

Waste management in South Africa, similarly to many other parts of the world particularly Southern Africa, has always been one of the very important elements of economic growth yet the least prioiritised. This was in terms of resource allocation as well as the regulatory provisions governing waste management in the country. It has however, along with global trends, gained prominence as more awareness on the impacts on the environment and human health has been achieved as well as recognition of the possible benefits which can be attained when waste is managed in a sustainable manner. Waste legislation was fragmented, with waste falling under the portfolios of different government departments such as Department of Health (health care waste), Minerals and Energy (mining waste), Transport (transportation of hazardous waste), Environmental Affairs (municipal and industrial waste) to mention a few. Following the promulgation of the National Environmental Management Act (NEMA) in 1998, which is the framework legislation which covers all environmental aspects, the White Paper on Integrated Pollution and Waste Management was introduced in the year 2000; preceded by the first National Waste Management Strategy published in 1999. These developments introduced a paradigm shift from the traditional waste disposal based approach of waste management, to a more preventative and integrated approach of waste avoidance, reuse and recycling, commonly known as the waste hierarchy approach.

The fragmentation of legislation presented loopholes and coordination challenges in terms of compliance monitoring and enforcement and necessitated a need to come up with an integrated piece of waste legislation. Despite the resistance form some sectors of government, business and non government organisation, the new National Environmental Management: Waste Act, hereinafter referred to as the "Waste Act", was promulgated and came into effect on 1 July 2009, a big milestone for waste legislation in the country. It is important to mention that environmental management in general and waste management in particular, is provided for in the Constitution of the country, section 24 of which states that everyone has a right to an environment that is not harmful to their health and well being and that the State must ensure that the environment and people are protected from pollution and ecological degradation through passing legislation and promoting sustainable economic development. The Waste Act is mainly based on the waste hierarchy approach and it prioritises waste avoidance, reuse, recycling, recovery of energy, treatment and safe disposal as a last resort. Another important element which is new in waste legislation is the provision for remediation of contaminated land which is linked to the "polluter pays principle" and is illustrated in figure 1 in order of prioritisation. 


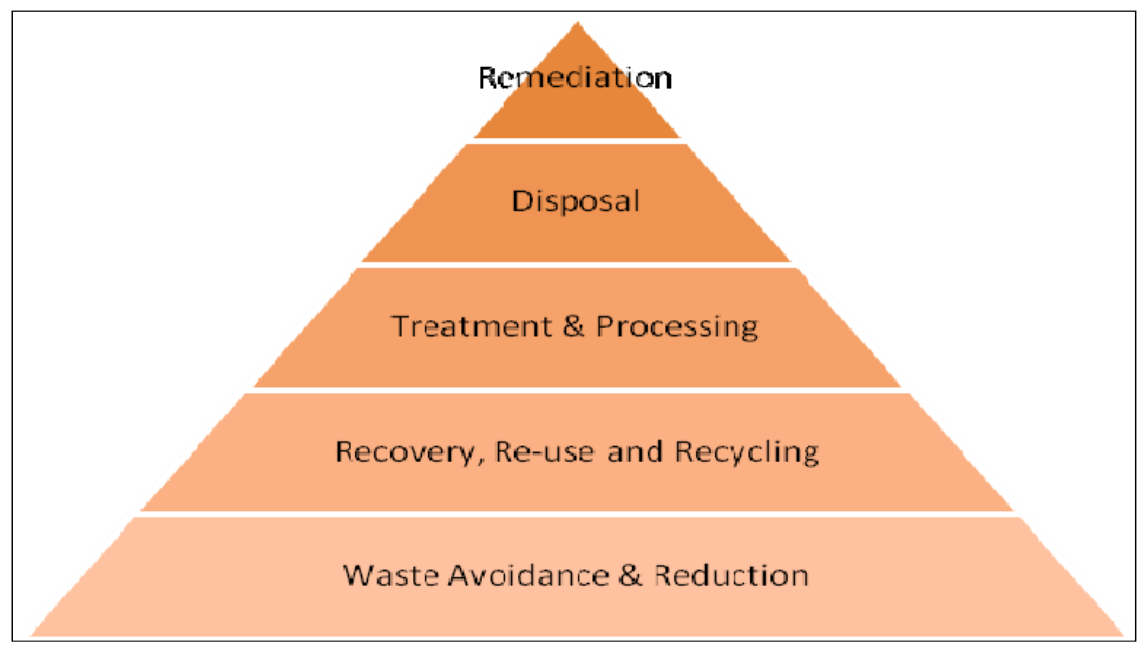

Figure 1: $\quad$ Waste hierarchy (source: NWMS 2010).

The Waste Act is housed under the national Department of Environmental Affairs, which is lead sector Department but work very closely with departments of Water Affairs, Transport, Trade and Industry, Cooperative Governance, Minerals, Energy, Human Settlement, Agriculture, and Education as waste is a cross cutting area of responsibility. Waste services are however provided by local government with provincial government having a concurrent role with national government of providing policy and legislative framework on waste management.

\subsection{Waste generation}

The new waste legislation comes in a country where generation of waste per capita was estimated at an average of $0.4 \mathrm{~kg}$ per day according to the State of the Environment Report (2006). As at 1997, waste generation in South Africa amounted to approximately 533 million tons per annum (MT/a) of which the majority comprised mining waste $(88 \%)$ while domestic and trade waste represented $1.5 \%$ and sewage sludge $0.1 \%$ (DWAF, 2001). These findings are illustrated in Figure 2.

The State of the Environment Report (DEAT, 2006) suggests that approximately $15 \mathrm{Mt} / \mathrm{a}$ of general waste is generated while the research paper towards the development of the National Waste Management Strategy (Purnell, 2009) estimated that general waste (domestic and trade waste) disposed at landfills in 2006/7 amounted to 24.1 million tons/annum. With the increase in population growth rate and society becoming more affluent; the amount of waste generated are growing as well as the complexity of waste streams, with the introduction of waste streams such as waste electronic equipment for example. 


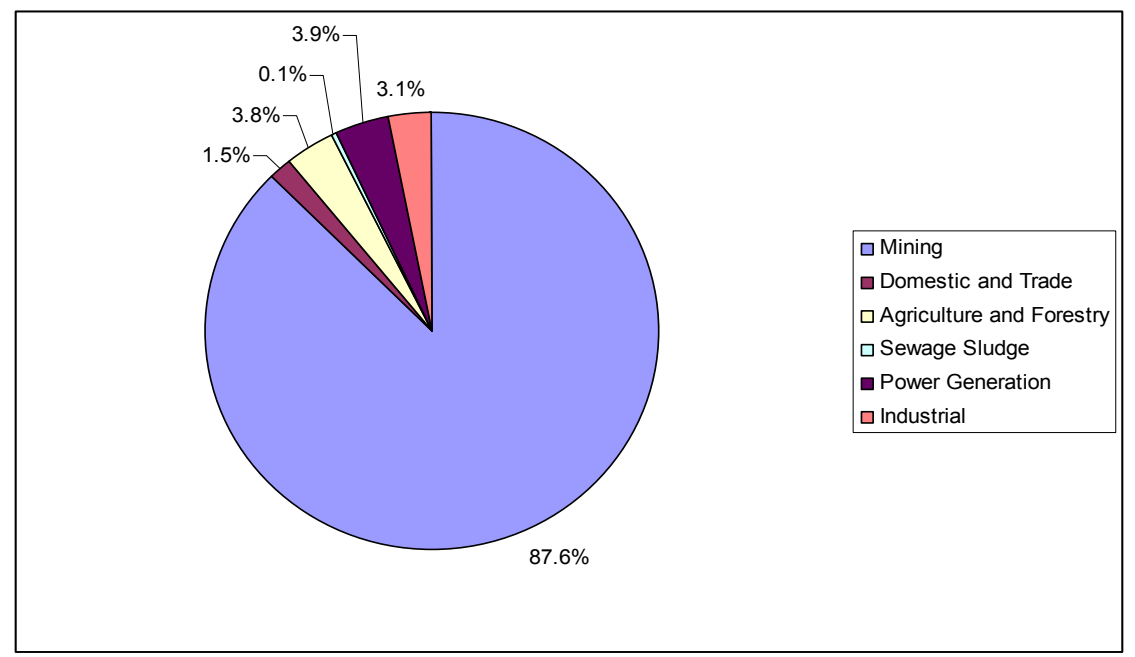

Figure 2: National waste generation rates in South Africa in 1997 (source DWAF, 2001).

\section{The new approach to waste management}

\subsection{Definition of waste}

The definition of waste has been and is still one of the controversial elements of waste legislation in the country and in many countries, in that some sectors look at it in an economic approach i.e. if it has value then it is not waste, whilst others base the definition on the basis of potential environmental impact if not properly managed. The Waste Act introduced a definition of waste, which went through extensive consultation with all sectors. Importantly for industry, the by products and activities that fall outside the definition of waste are treated outside the provisions of the Act. The definition of waste, as per the Waste Act, is as follows:

"waste" means any substance, whether or not that substance can be reduced, re-used, recycled and recovered-

(a) that is surplus, unwanted, rejected, discarded, abandoned or disposed of;

(b) which the generator has no further use of for the purposes of production;

(c) that must be treated or disposed of; or

(d) that is identified as a waste by the Minister by notice in the Gazette, and includes waste generated by the mining, medical or other sector; but -

(i) a by-product is not considered waste; and

(ii) any portion of waste, once re-used, recycled and recovered, ceases to be waste; 
Given the exclusion of by-products, their definition in terms of the Waste Act is also important:

"by-product" means a substance that is produced as part of a process that is primarily intended to produce another substance or product and that has the characteristics of an equivalent virgin product or material;

Due to differentiated interpretation of the legislated definition, the Department of Environmental Affairs has published an interpretation document in order to clarify this matter and to ensure that there is uniformity in the interpretation across the country. Although the definition of waste covers all waste, the new Waste Act does not apply to radioactive waste, explosives, mining stockpiles and residue deposits and disposal of animal carcasses as these are already covered in other legislation, a leg to stand on for most critics of the new waste legislation.

\subsection{Adopted regulatory tools in the new Waste Act}

The Waste Act is framework legislation, meaning that it provides an overall framework for waste legislation in the country and gives the government powers to pass regulations for various elements of waste management. This is because waste streams require various approaches and therefore a one size fits all approach could have unintended impediments or consequences. This relates to for example; regulatory provisions for waste tyres cannot be applied in the regulation of industrial effluents or waste oil. The Act adopts an array of tools which can be applied in waste management which range from very strict tools such as declaration of priority waste and listing and licensing of waste management activities to self and co-regulatory measures such as setting of norms and standards and Industry Waste Management Plans (IndWMPs). The tools are briefly described below:

\subsubsection{Norms and standards}

National norms and standards provide the foundation of the regulatory system. The Waste Act allows for an integrated system of mandatory and non mandatory norms and standards across the national, provincial and local government. Norms and standards provided for in the Act include:

a) Classification of waste.

b) Planning and delivery of waste management services.

c) The storage, treatment and disposal of waste (including the planning and operation of waste treatment and waste disposal facilities).

d) Contaminated land and soil quality etc.

Norms and standards will mainly promote environmentally sound handling and management of waste, and might not have a requirement to undertake an environmental impact assessment process and apply for a waste license, depending on the assessment on a case by case basis. The aim is to minimise the legislative burden on industry and encourage the movement towards waste 
reduction, reuse, recycling and recovery of waste in an environmentally sound manner. The Department is currently developing a series of norms and standards with an aim to de-list some of the activities from Waste Management Activity List, which lists activities that cannot be undertaken without a waste management authorisation (e.g. storage of waste, landfill gas extraction, acceptable use of certain waste streams) and until such time that these are implemented, it remains a mystery whether it would be beneficial. Standards for the domestic waste collection have also been developed to assist local government in providing uniform if not consistent services across the board. This approach will however, require government to also strengthen its compliance and monitoring arm to ensure that the norms and standards are adhered to in order to prevent environmental damage.

\subsubsection{Waste information system}

One of the biggest challenges in waste management is lack of accurate and reliable waste information to aid proper planning for both government and industry. The web-based South African Waste Information System (SAWIS) was developed prior to the promulgation of the Waste Act and relied on voluntary registration and reporting. This system incorporated in it lessons learnt from countries such as Denmark, Swaziland etc and attempts to make reporting as cost effective as possible for the facilities required to report. Registration and reporting to the waste information systems, be it at national or provincial level, is now a mandatory requirement and it is expected that it will improve the reporting rate which will allow for the publication of annual waste reports. There is however a need to undertake a baseline studies as a basis for trend monitoring going forward.

\subsubsection{Industry Waste Management Plans}

Industry Waste Management Plans (IndWMPs) are the main co-regulatory instrument within the waste management system. They describe the waste related issues within an industry, and specify how the industry will address these issues, giving specific actions, targets and timeframes. Part 7 of the Waste Act, section 28 to section 34, sets out the requirements for IndWMPs, which may be prepared on a mandatory or voluntary basis. The Minister of Environmental Affairs (hereinafter referred to as 'the Minister') may request an IndWMP for waste generating activities that affect more than one province or which occur in more than one province. The provincial Member of Executive Committee (MEC) may request an IndWMP for waste generating activities within the province, provided that such a plan has not already been requested by the Minister. Industry may also prepare and submit plans on a voluntary basis. Section 30 (2) of the Waste Act indicates the information that the Minister or MEC may specify in requesting an IndWMP. In these plans, Industry is required to address matters such as waste streams produced, how they intend implementing waste minimisation strategies, how they intend financing take-back initiatives to ensure that they take responsibility of their products post consumer stage and set targets for minimisation and diversion from landfills. IndWMP are currently at a very initial stage and but have been positively welcome by industry as an appropriate 
co-regulatory tool which will somewhat recognise some of the efforts already in place prior to the promulgation of the Waste Act. The initial prioritised plans include:

a) Tyres industry to manage waste tyres.

b) Paper and Packaging industry to manage packaging and paper waste.

c) Lighting industry manufacturing mercury containing lamps e.g. CFLs.

d) Pesticide Industry to manage residual pesticides and pesticide containers.

It is envisaged that further plans will be submitted by industries on a voluntary basis, once the uniform guidelines have been finalised and published by the Minister.

\subsubsection{Listing and licensing}

The Waste Act gives powers to the Minister to publish a list of activities which have or are likely to have a detrimental effect on the environment and specify the requirements for conducting such activities. The published list established two categories of waste management activities, both of which require licensing:

Category A: These activities require a basic assessment process as defined in environmental impact assessment (EIA) regulations provided in NEMA to be completed in order to obtain a license for the activity. A basic assessment process is appropriate where the environmental impact of a particular activity is well understood and limited in scope. The list also has thresholds in terms of either the volume of waste or the size of the operational area or full capacity of the facility.

Category B: As a licensing requirement, these activities require a full assessment report in terms of the Environmental Impact Assessment regulations. A full assessment process is appropriate where the potential scope and extent of environmental impacts is not well understood, or is likely to be significant. This is mainly for hazardous waste activities or large scale waste disposal sites where the foot print is significantly large.

There are plans to publish Category $\mathrm{C}$ of the listed activities which will not require a waste license but will be subjected to norms and standards. The process of licensing can be long and expensive but is the most appropriate tool to ensure that all activities can be subjected to some conditions and that the potential environmental impact is mitigated, and where they cannot be mitigated, a license in not issued.

\subsubsection{Priority wastes}

The Waste Act provides for the declaration of priority wastes which must be published nationally. This is one of the more interventionist measures, primarily because the consequent waste management measures can severely limit or prohibit the generation of that waste, may require detailed registration and reporting of it, may limit its import and export, and ultimately culminate in a 
waste being phased out completely. Currently, no priority waste streams have been published; however, there are existing and potential priority wastes which will be further investigated. Regulations for the prohibition of asbestos have been promulgated in terms of the Environmental Conservation Act (1989) prior to the Waste Act coming into force. These regulations effectively declare asbestos as a priority waste and they remain effective.

According to the draft National Waste Management Strategy (2010) wastes to be considered for declaration as priority wastes include polychlorinated biphenyls (PCBs) and mercury waste. Their destruction through treatment processes is difficult and often extremely hazardous. PCBs are classified as a persistent organic pollutant under the Stockholm Convention, to which South Africa has acceded. Mercury on the other hand has a chemical element, most commonly used in scientific apparatus, CFLs and batteries. Mercury is also highly toxic, and can cause severe poisoning, debilitating neurological conditions and in some instances death. Pollution of water sources by mercury causes serious ecological damage. The use of mercury is severely controlled in several countries.

\subsubsection{Extended producer responsibility}

The Waste Act makes provision for the Minister to require any producer to undertake Extended Producer Responsibility (EPR). EPR applies to instances in which the nature of the waste from products is of sufficient threat to require producers to take responsibility for aspects of a products management post consumer. EPR programmes can focus on both the beginning stages of a product's lifecycle i.e. how to avoid the generation of waste, and on the end stages i.e. how to manage its use and disposal. Whilst there are still challenges and gaps, South Africa has been fortunate to have voluntary initiatives or EPR programmes which are industry led that deal with waste streams such as used oil, waste tyres, e-waste etc.

\subsubsection{Remediation of contaminated land}

As indicated previously, this section is new in waste legislation in the country and provides for the identification and declaration of investigation areas where high risk activities have or are suspected to have occurred. Such areas or sites will then be registered in the national register of contaminated land and the Minister can require the owners or the polluters to undertake site assessment. In instances where land has been contaminated, the polluter will have to remediate such a site at own cost, to acceptable norms and standards. This provision will also be linked to the property registration office whereby the transfer or sale of any land which appears in the register of contaminated sites must be declared as such before a transfer can take place. It is worth while to mention that this provision applies retrospectively, but is currently not in force. It will only be brought into effect once the norms and standards for remediation and soil quality are in place. In a country with a history of high risk activities such as mining of gold and an array of industrial sites which were previously not subjected to strict waste regulation, this section will potentially provide for redress of the past contamination which affect human health, water resources, agricultural land and 
mainly affect the poor who may not be aware of the impacts. Government will, in cases where the polluter cannot be traced, be responsible for remediation of such land, a cost that can potentially cripple the fiscal allocations. This section has obviously received some level of resistance from the 'would be culprits' when it is brought into force.

\subsubsection{Economic and fiscal instruments}

The Waste Act provides various legislative measures for the use of economic instruments. These will be applied within the context of the overall fiscal and taxation policy established by the Ministry of Finance, and will require careful consideration of implications. The selection and use of economic measures, including pricing, taxation, subsidies, incentives and fiscal measures will also be aligned with the principles established by NEMA, including the 'polluter pays' principle. The Department of Environmental Affairs (DEA) has through the development of the National Waste Management Strategy; identified some of the instruments which could possibly be explored and will be considered for implementation. These are:

a) Deposit Refund Schemes: These schemes are most suitable for products that are easy to identify and handle; feasible to use and/ or recycle; require careful disposal (e.g. batteries); and where cooperation is feasible between producers, retailers and consumers. Deposit refund schemes will be considered for specific waste streams where the private sector is not effectively addressing the issue.

b) Waste Disposal Taxes: Waste disposal taxes address the external social and environmental costs of waste disposal and provide pricing that takes into account the waste generation and disposal decision by private actors. These only impact on waste generation if the generators experience increases in costs. The risk of waste streams being diverted to incineration and illegal disposal are high. Waste disposal taxes require effective regulation and monitoring of landfill sites to be in place. Where a specific waste disposal site is underpriced the capacity to tax a specific site will be considered.

c) Product Taxes: Product taxes will be directed at products or materials for which there exists a policy intention to diminish the product or material over time or remove it from use or production.

d) Tax interventions for hazardous waste disposal: This will be considered in instances where more effective management of hazardous waste generators is required.

The Waste Act also provides for the establishment of recognition programmes for public recognition of significant achievements in the area of waste avoidance, minimisation or other forms of waste management in order to make the public aware of sound waste management practices. 


\section{Institutional arrangements and planning matters}

One of the key aspects for the successful implementation of any legislation is the human and institutional capacity which is put in place. South Africa has been suffering from lack of capacity at local government level and other spheres of government dedicated to waste regulation and management. In a study that was undertaken by the Department of Environmental Affairs in 2007, it was discovered that lack of capacity in government presented the most challenge in terms of waste management. Through the Waste Act, the national department, provincial departments as well as all the local municipalities are required to designate waste management officers. These officers will be responsible for coordination and implementation of the national waste management strategy as well as ensuring compliance to the Waste Act. Over an above that, all municipalities are required to develop Integrated Waste Management Plans (IWMPs) which will address how they intend rolling out waste services to all households, identify infrastructure requirements as well as waste minimisation measures and projects which will be implemented to achieve the objectives of the Act.

\section{The National Waste Management Strategy as an implementation instrument}

The Minister of Environmental Affairs is required by the Waste Act to establish within two years of the Act coming into effect, the National Waste Management Strategy (NWMS). This is a strategy that will address the objects of the Act and will be the main document to guide all sectors on the priorities, objectives and targets for waste minimisation towards the achievement of the waste hierarchy. The draft NWMS (2010), which has been published for public comment already, set a scene for engagement on waste management approaches in the public, private sector arena.

\section{Compliance monitoring and enforcement}

The South African government, through the promulgation of NEMA, introduced a compliance arm called Environmental Management Inspectors (EMIs) and they are already making enroutes in ensuring compliance and bringing to book everyone who is not complying. The EMIs are also monitoring compliance to the provisions of the Waste Act, although there is a need to increase the numbers and offer specialised training relating to waste management. This is a considerable effort that government has put in place which will potentially guarantee consistent compliance as everyone is aware that they can be targeted for inspection unannounced. This effort is also supported by more stringent penalties outlined in the Act with a maximum of R10 million fine or imprisonment period not exceeding 10 years or both and this can be a great deterrent to non 
compliance. It remains to be seen as the Act is implemented whether this perceived deterrent will be a reality.

\section{Possible benefits and challenges}

The implementation of a waste hierarchy approach through the provisions of the Act will have many benefits if implemented effectively and efficiently. The main benefits will emanate from waste avoidance through the implementation of cleaner production strategies at production level to ensure that the generation of waste is avoided and minimised. It is however acknowledged that waste generation cannot at all times be avoided therefore the diversion of waste from landfills which will save airspace and minimise the ecological foot print of these mega waste burial sites, must be prioritised. The associated impacts of landfill sites on water resources, air quality as well as the costs associated with their management will also be averted. The use of raw materials will be optimised through utilisation of recycled material instead of virgin material and through recovery of energy from waste such as in the cement kilns. The reuse of waste which includes acceptable use of coal boiler ash for brick making and other waste streams through industrial waste exchange schemes will also be beneficial. The reduction of the number landfill sites will also contribute climate change mitigation measures the country is committed to.

This does not come without challenges, in a country where nearly $50 \%$ of the population does not receive waste services and mostly cannot afford to pay for the service. Some of the landfill sites, particularly municipal landfills are still not operated according to minimum requirements and it goes with lack of technical capacity at that level. The limited fiscal allocation to waste management is still a course for concern as well as limited public awareness of waste issues. The drive towards improved waste management practices is however driven by the political will which exists and it is expected that services will be rolled our to all with the promotion of community based waste collection and recycling schemes. These will also contribute to job creation and small business development, as a built-up on the existing initiatives.

\section{Conclusion}

Waste management is one of the unavoidable consequences of any development and the more societies develop and become more affluent, the volume and complexity of waste streams also increases. Coming from a history of fragmented waste legislation, lack of coordination, traditional disposal based waste management approaches and lack of prioritisation of waste management in general; the country has come a long way. The promulgation of the Waste Act has been a great milestone and provides a potential for a change in the approach, particularly promoting the waste hierarchy approach. It would be very interesting to evaluate how the legislative tools such as IndWMP, norms and standards, declaration of priority wastes, listing and licensing etc, will translate into tangible benefits in practice. It is however acknowledged that there is still a long 
way to go and challenges with fiscal allocations for waste management and capacity at local government level remain amongst key concerns, particularly in relation to provision of waste services to all citizens including the poor and vulnerable. Overtime, the implementation of the national waste information system should provide the basis for evaluation of these interventions to assess whether the approaches are effective. It is simply impossible to say whether the Waste Act has any significant or tangible benefits within only one year of implementation, however, the will and commitment all at levels of society is what will determine its success.

\section{References}

[1] Department of Environmental Affairs (DEA).2010. National Waste Management Strategy First Draft for public comment. February 2010. Pretoria.

[2] Department of Environmental Affairs (DEA).2010. Draft Municipal Sector Plan. Pretoria.

[3] National Environmental Management Act 107 of 1998 (NEMA). 1998. Republic of South Africa. Pretoria.

[4] National Environmental Management: Waste Act 59 of 2008. 2008. Republic of South Africa.

[5] Department of Environmental Affairs and Tourism (DEAT).2007. Assessment of the Status of waste service delivery and capacity at local government level. Department of Environmental Affairs and Tourism, Pretoria.

[6] Department of Environmental Affairs and Tourism (DEAT). 2006. State of the Environment Report. Pretoria.

[7] Department of Water Affairs and Forestry (DWAF). 2001. Waste Generation in South Africa. Water Quality Management Series. Pretoria.

[8] Purnell, G. 2009. National Waste Quantification and Waste Information System Research Paper towards the development of a National Waste Management Strategy.

[9] Republic of South Africa (RSA) .1996. The Constitution of the Republic of South Africa, Act No 108 of 1996. 